\title{
DEATH IN ASTHMATICS
}

\author{
BY \\ B. S. CARDELL AND R. S. BRUCE PEARSON \\ From the Departments of Pathology and Medicine, King's College Hospital Medical School, London
}

(RECEIVED FOR PUBLICATION APRIL 20, 1959)

In recent years it has become accepted that asthma is not the benign disorder which leads to discomfort but never to death that it was thought to be 30 years ago. Following the pioneer paper of Huber and Koessler (1922), a number of workers have published series of fatal cases and commented on the pathological findings. This literature has been reviewed by Unger (1952), by Earle (1953), and by Robertson and Sinclair (1954) and more recent reports are those of Alexander (1958) and Williams and Leopold (1958).

It is obvious from a study of this literature that the term asthma is often used to include cases of varying aetiology and to describe a syndrome rather than a disease. Until a clearer notion of the pathogenesis of asthma is obtained some confusion of terminology will inevitably continue. Meanwhile it is firmly established that asthma can be lethal, though the role of allergy, of infection, and of several other factors is not yet fully elucidated. In this paper we hope to show that the comparison of clinical and pathological features of fatal cases of asthma can still provide useful information.

\section{Material and Methods}

This study is based on the findings in 68 fatal cases of asthma, most of which had been observed during life by one of us for many years: 22 of these are referred to in a recent survey (Pearson, 1958). In each case death was considered, on clinical grounds, to be directly or indirectly related to the asthmatic state from which the patient suffered.

The word " asthma" is used here to signify a symptom complex characterized by attacks of dyspnoea of long or short duration, associated with widespread expiratory wheezing rhonchi, intermittent at least in the early stages, though persistent in the terminal phases in some long-standing cases.

In most cases the asthma appeared to be primary. In 16 cases, however, asthma apparently developed secondary to bronchitis. It is considered that the phrase "asthma secondary to bronchitis" indicates more clearly the conception we have in mind than two other terms in common use. "Asthmatic bronchitis" leaves some doubt as to which is the primary disease: "bronchitis with bronchospasm" implies a knowledge of functional pathology that we do not possess and is almost certainly incorrect since oedema and mucus plugging in these cases are at least as likely as muscle spasm to cause respiratory obstruction.

Post-mortem examination was performed on 43 cases. In 31 cases the necropsy was carried out by one of us or material was available for study, and the detailed observations on pathology are based on this group: some of these cases were included in an earlier report (Cardell, 1956). Particular attention was paid to examination of the lungs and in many cases paper-mounted whole lung sections were prepared using the technique introduced by Gough (Gough and Wentworth, 1949 ; Gough, 1957-58). In addition, information about the macroscopic findings was available on eight necropsies undertaken by pathologists at the request of the coroner and on four necropsies carried out at other hospitals.

\section{Clinical Features}

The main clinical features of individual cases in this series are summarized in Table $I$. The overall sex incidence was equal (males, 35; females, 33). In cases of primary asthma female deaths exceeded male deaths up to the age of 40 years (males, nine ; females, 14) whereas the sex incidence was equal after that age (males, 14 ; females, 15). In deaths from asthma secondary to bronchitis males exceed females (males, 13; females, three).

In Table II the cases are grouped, by decades, according to both age at onset of asthma and age at death. It can be seen that more patients died in the sixth decade than in any other: if the figures for primary asthma are considered separately, by subtracting the figures in brackets from the totals, the fifth decade is the peak period. The onset in patients dying from primary asthma was usually in the first three decades and death occurred before the age of 50, whereas in those in whom asthma was secondary to bronchitis it rarely started before 50 years of age. 
TABLE I

SUMMARY OF CLINICAL FEATURES

\begin{tabular}{|c|c|c|c|c|c|c|c|c|}
\hline \multirow[b]{2}{*}{$\begin{array}{l}\dot{0} \\
z \\
\tilde{J} \\
\tilde{J}\end{array}$} & \multirow[b]{2}{*}{ ฝั } & \multirow[b]{2}{*}{ 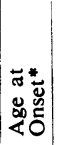 } & \multirow[b]{2}{*}{ | } & \multicolumn{4}{|c|}{ Precipitating Factors } & \multirow[b]{2}{*}{$\begin{array}{l}\text { Clinical Mode } \\
\text { of Death }\end{array}$} \\
\hline & & & & 递 & 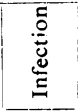 & 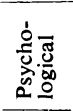 & 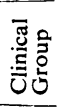 & \\
\hline 1 & $F$ & 712 & $7 / 12$ & + & $t^{t}$ & 0 & $E$ & Status \\
\hline 2 & & 1 & 3 & 0 & ++ & 0 & E & , \\
\hline 3 & $\mathbf{F}$ & 1 & $\begin{array}{l}13 \\
35\end{array}$ & + & $\begin{array}{l}0 \\
0\end{array}$ & $\begin{array}{l}0 \\
0\end{array}$ & $\begin{array}{l}\mathrm{FE} \\
\mathrm{FE}\end{array}$ & $\ddot{~}$ \\
\hline $\begin{array}{l}4 \\
5\end{array}$ & $\mathbf{M}$ & 1 & $\begin{array}{l}35 \\
44\end{array}$ & $+0^{+}$ & $\begin{array}{l}0 \\
t+t\end{array}$ & + & & ,", \\
\hline 6 & & 1 & 2 & 0 & 0 & 0 & IN & , \\
\hline $\begin{array}{l}7 \\
8\end{array}$ & $\mathbf{M}$ & 1 & $\begin{array}{l}15 \\
24\end{array}$ & ++ & $\begin{array}{l}0 \\
++\end{array}$ & $\begin{array}{l}0 \\
0\end{array}$ & $\underset{\mathrm{I}}{\mathrm{OA}}$ & $\begin{array}{l}\text { is } \\
\text { Imaticus }\end{array}$ \\
\hline 9 & M & 2 & 22 & $+t$ & $T$ & 0 & FE & , \\
\hline 10 & $F$ & 2 & 24 & ++ & 0 & ++ & IN & ," \\
\hline 12 & $\mathbf{M}$ & 2 & $\begin{array}{l}26 \\
32\end{array}$ & + & ++ & 0 & $\mathrm{OA}$ & ,", \\
\hline 13 & M & 2 & 42 & 0 & 0 & 0 & & aneous \\
\hline 14 & F & 3 & 15 & $+t$ & 0 & 0 & PA & State \\
\hline & & 3 & 20 & 0 & ++ & 0 & & , \\
\hline 16 & $F$ & $\begin{array}{l}3 \\
3\end{array}$ & $\begin{array}{l}26 \\
32\end{array}$ & $\begin{array}{l}++ \\
++\end{array}$ & $\begin{array}{c}0 \\
+++\end{array}$ & $\begin{array}{l}0 \\
0\end{array}$ & $\begin{array}{l}\mathrm{PA} \\
\mathrm{FE}\end{array}$ & Cor pl \\
\hline $18>2>>2>$ & M & 3 & 40 & $+t$ & $1+$ & 0 & $\mathrm{FE}$ & cus \\
\hline 19 & M & 3 & 50 & 0 & + & 0 & IN & Act \\
\hline 20 & $\mathbf{M}$ & 4 & 24 & 0 & ++ & 0 & FE & Sta \\
\hline 2 & $\mathbf{M}$ & $\begin{array}{l}5 \\
6\end{array}$ & $\begin{array}{l}49 \\
42\end{array}$ & $\begin{array}{l}0 \\
+\end{array}$ & $\begin{array}{l}0 \\
++\end{array}$ & $\begin{array}{l}0 \\
0\end{array}$ & IN & $\begin{array}{l}\text { Ac } \\
\text { Po }\end{array}$ \\
\hline & & & & & & & & \\
\hline $\begin{array}{l}23 \\
24\end{array}$ & & $\begin{array}{r}6 \\
10\end{array}$ & \begin{tabular}{l|l}
65 \\
46
\end{tabular} & $\begin{array}{l}0 \\
0\end{array}$ & + & $\begin{array}{l}t+t \\
t+t\end{array}$ & $\begin{array}{l}\mathbf{P} \\
\mathbf{P}\end{array}$ & \\
\hline 25 & $\mathbf{M}$ & 12 & 39 & $+t+$ & + & 0 & FE & An \\
\hline 26 & $F$ & 1 & 56 & $++t$ & + & 0 & PA & Sta \\
\hline 27 & $\mathbf{F}$ & 16 & 30 & + & $+t+$ & + & IN & ," \\
\hline $\begin{array}{l}28 \\
29\end{array}$ & $\mathbf{M}$ & $\begin{array}{l}11 \\
21\end{array}$ & $\begin{array}{l}45 \\
43\end{array}$ & + & ++ & ++ & & .. \\
\hline 30 & & 21 & 45 & $+t$ & & 0 & $P A>>>>$ & . \\
\hline 31 & $\mathbf{F}$ & 22 & 33 & ++ & 1 & ++ & & \\
\hline $32+2>2>$ & $\mathrm{F}$ & 22 & 46 & $\begin{array}{l}0 \\
+\end{array}$ & $\begin{array}{c}++ \\
+\end{array}$ & $\begin{array}{r}0 \\
++\end{array}$ & $\mathrm{I}$ & $\begin{array}{l}\text { Acu } \\
\text { Stat }\end{array}$ \\
\hline 34 & $\mathbf{F}$ & 24 & 53 & 0 & $t+$ & $1+t$ & $\mathbf{P}$ & , \\
\hline & & & 29 & 然 & & ++ & $\mathrm{FE}$ & , \\
\hline & & & 4 & 0 & & + & & ", \\
\hline & $\mathbf{M}$ & 27 & $\begin{array}{l}55 \\
49\end{array}$ & 0 & + & +++ & $\mathbf{I}$ & ,. \\
\hline $\begin{array}{l}38 \\
39\end{array}$ & $\stackrel{M}{\mathrm{~F}}$ & $\begin{array}{l}27 \\
28\end{array}$ & \begin{tabular}{l|l}
499 & \\
34 &
\end{tabular} & $\begin{array}{l}0 \\
++\end{array}$ & ++ & $\begin{array}{l}0 \\
++\end{array}$ & PA & hma \\
\hline 40 & $\mathbf{M}$ & 29 & 55 & 0 & & 0 & $\mathrm{R}>\mathrm{C}$ & $\begin{array}{l}\text { hopneu- } \\
\text { a. Hyper- } \\
\text { e heart }\end{array}$ \\
\hline 41 & & 3 & 48 & 0 & +1 & 0 & & Sta \\
\hline 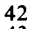 & & & & ++ & & 0 & $\mathbf{D}$ & Acu \\
\hline & & & & 0 & & 0 & & \\
\hline 44 & 4 & & 6 & + & + & 0 & & Stat \\
\hline 45 & & & 6 & 0 & & S & $P_{2}$ & ," \\
\hline 46 & $\mathbf{M}$ & 4 & 5. & 0 & $+\div$ & 0 & B & \\
\hline 477 & $\mathrm{~F}$ & & 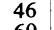 & 0 & + & + & $I_{V}$ & Post \\
\hline & & & & 0 & & $i$ & IN & \\
\hline & $\mathrm{F}$ & 46 & 66 & 0 & & + & & tatu \\
\hline & $\mathrm{F}$ & $\begin{array}{l}48 \\
48\end{array}$ & 52 & ++ & & ++ & ${ }_{B}$ A & ," \\
\hline $\begin{array}{l}51 \\
52\end{array}$ & $\mathrm{~F}$ & $\begin{array}{l}48 \\
48\end{array}$ & 56 & 0 & ++ & 0 & I & Aft' \\
\hline 53 & $\mathbf{M}$ & 49 & 5 & 0 & . & 0 & B & Status \\
\hline 54 & iv & & 6 & & & 0 & 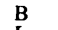 & (1) \\
\hline $55>>>>>$ & $N$ & 50 & 5 & & $+0^{+}$ & 0 & I & , \\
\hline & & & & & & 0 & & ," \\
\hline & & & & & $+t$ & 政 & & ,, \\
\hline & & & 5 & & & 0 & & \\
\hline & & & & & & & & \\
\hline 6 & M & 54 & 58 & 0 & $0^{+}$ & 0 & IN & $\mathrm{Co}$ \\
\hline 63 & $\mathrm{~F}$ & 60 & $\begin{array}{l}58 \\
61\end{array}$ & $\begin{array}{l}0 \\
0\end{array}$ & $\begin{array}{l}0 \\
++\end{array}$ & $\begin{array}{l}0 \\
0\end{array}$ & ${ }_{B}^{\text {IN }}$ & $\begin{array}{l}\text { Sta } \\
\text { Hy }\end{array}$ \\
\hline 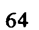 & $\mathbf{M}$ & $60>>>2>0$ & & 0 & & 0 & B & Status asthmaticus \\
\hline & & & 6 & O & & 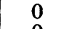 & B & (2) \\
\hline 00 & M & 63 & 6 & 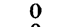 & 1 & 0 & D & 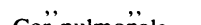 \\
\hline $\begin{array}{l}67 \\
68\end{array}$ & $\begin{array}{l}\mathbf{M} \\
\mathbf{M}\end{array}$ & $\begin{array}{l}64 \\
72\end{array}$ & $\begin{array}{l}69 \\
72\end{array}$ & $\begin{array}{l}\mathbf{0} \\
\mathbf{0}\end{array}$ & $+t+$ & $\begin{array}{l}0 \\
0\end{array}$ & $\begin{array}{l}\text { B } \\
\text { B }\end{array}$ & $\begin{array}{l}\text { Cor pulmonale } \\
\text { Pneumonia }\end{array}$ \\
\hline & & & & & & & & \\
\hline
\end{tabular}

* Cases arranged in order of age at onset of asthma

FE-flexural eczema. PA-pollen allergy. OA-other allergy.
TABLE II RELATION BETWEEN AGE AT ONSET OF ASTHMA ANDE

\begin{tabular}{|c|c|c|c|c|c|c|c|c|c|}
\hline \multirow{2}{*}{$\begin{array}{c}\text { Age at } \\
\text { Onset } \\
\text { (Years) }\end{array}$} & \multicolumn{8}{|c|}{ Age at Death (Years) } & \multirow{2}{*}{ 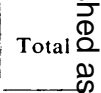 } \\
\hline & $0-9$ & $10-19$ & $20-29$ & $30-39$ & $40-49$ & $50-59$ & $60-69$ & $70+$ & \\
\hline $\begin{array}{c}0-9 \\
10-19 \\
20-29 \\
30-39 \\
40-49 \\
50-59 \\
60-69 \\
70+\end{array}$ & 3 & $\begin{array}{l}3 \\
0\end{array}$ & $\begin{array}{l}7 \\
0 \\
2\end{array}$ & $\begin{array}{l}3 \\
2(1) \\
2 \\
1\end{array}$ & $\begin{array}{l}5 \\
1 \\
5 \\
2 \\
1\end{array}$ & $\begin{array}{l}1 \\
1 \\
3(1) \\
0 \\
5(3) \\
6(5)\end{array}$ & $\begin{array}{l}1 \\
0 \\
0 \\
1 \\
4(1) \\
2 \\
5(4)\end{array}$ & $\begin{array}{l}0 \\
1 \\
0 \\
0 \\
0 \\
0 \\
0 \\
1(1)\end{array}$ & $\begin{array}{r}23 \\
5(1) \\
12(1) \\
4 \\
10(4) \overrightarrow{0} \\
8(5) \\
5(4) \\
1(1) \\
\text {. }\end{array}$ \\
\hline Total & 3 & 3 & 9 & $8(1)$ & 14 & $16(9)$ & $13(5)$ & $2(1)$ & 68 (16) \\
\hline
\end{tabular}

N.B. The figure in brackets indicates asthma secondary to bron $\omega$ chitis. To obtain the number of cases of primary asthma in the group this figure must be subtracted from the larger one immediately preceding it.

A study of the precipitating factors (Table $I P_{0}$ shows some relation to age. Allergic factors (clinical history of sensitivity confirmed by skin 3 testing) were present in 24 of the 44 cases starting before the age of 40 years but in only two of the 24 cases starting later. Infection (the presences of pus and in many cases of pathogenic bacteria. in the sputum) was the commonest factor encountered and its incidence increased with age: it was recognized in 34 of the 44 patients starting before the age of 40 and in 21 of the 24 cases beginning later. Psychological precipitating $\mathbb{Q}$ factors (personality defect, situations causing $\underset{\vec{P}}{\vec{F}}$ emotional disturbances related to exacerbations 3 of asthma but not anxiety secondary to the asthmaitself) were found in 13 and seven cases respec=0 tively in the two age groups: the highest incidence was in those in whom asthma started between the ages of 10 and 50 years.

The patients have been divided into the following clinical groups each of which will be 3 . briefly discussed:

Flexural Eczema Group.-There were 11 patients in whom asthma was associated with flexural eczema and, in most, also with rhinorrhoea. Six were males and five females? In nine, asthma began before 4 years of age. Añ family history of asthma was present in four? Allergic sensitivities were present in eight including 0 three with sensitivity to foods and one to aspirin. N Psychological factors played some part in three.0

This group was considered to be primarilyo allergic in origin, but infective episodes were present in seven patients and one of these had? bronchiectasis. Two patients had severe pigeonto chest and two were markedly kyphotic. Nine died in status asthmaticus, one from anaphylaxis some seconds after a desensitizing injection of pollen, and one with cor pulmonale. 
Pollen Group.--Eight patients were sensitive to grass pollen, seven female and one male. Two others included in the flexural eczema group were also sensitive to grass pollen; one of them was the patient mentioned above who died as the result of pollen desensitization. All had a history of many years of asthma or hay-fever, or both, and gave positive skin reaction to pollen. In all, attacks of asthma were more frequent during the summer months, but also occurred at other periods of the year. A family history was present in three. Previous attacks of status asthmaticus at this time of the year were reported in six, in one for 10 years before death, in one for four years, in three the first attack of status asthmaticus had occurred only three years before death, and one patient died suddenly at home shortly after her discharge from hospital after her first attack of status asthmaticus. Five patients died in the summer months, but infection was present at the time of death in two. Three died in the winter, with severe infection in two and low-grade infection in the third.

Other Allergic Cases.-Two males and two females form this small group and in them allergic sensitivity was judged to have played an important part at some stage of the illness. One only had a family history of asthma. All were sensitive to common inhalants and one with nasal polyps was also sensitive to aspirin. One had bronchiectasis and died in status asthmaticus with evidence of bronchopneumonia at necropsy, two died in status asthmaticus at home, and one in anaphylactic shock after an injection of "pyelectan" for renal tract investigation.

Psychological Group. -- This group was composed of three males and three females, in whom overwhelming emotional factors were present. A family history of asthma was obtained in three cases. Infection was recorded in three. Case 24 has already been recorded fully by Leigh (1955). Marital difficulties played an important part in three, in one depression followed financial loss and death of a friend, and in another attacks of status asthmaticus began during financial difficulties with loss of self-esteem because of inability to repay money that had been borrowed. All died in status asthmaticus.

INFECTIVE GrouP.-In this group of 13 patients, eight males and five females, infection was the predominant factor. It was clear from the case histories, however, that attacks of asthma antedated infective symptoms - often by many months or even years. In this group bronchitis or lung infections were superimposed on pre-existing asthma in contrast to the bronchitic group, described later, where asthma developed secondary to respiratory tract infections.

In all cases in this group pus was repeatedly found in the sputum from which a variety of pathogenic bacteria were cultured, including Staphylococcus aureus in five, Streptococcus pneumoniae in three, Haemophilus para-influenzae in two, and Haemophilus influenzae and Escherichia coli once each: in three cases pathogens were not obtained. Other features included a significant emotional factor in nine cases, a family history of asthma in four, mild allergic sensitivity in four, and nasal polyps in two. Eight patients had high blood eosinophil counts ranging from 540 to 1,900 per c.mm. Asthmatic attacks tended to be long and sputum was never copious. These cases correspond closely with the "intrinsic" group of cases described by Rackemann (1944).

Nine of these patients died in status asthmaticus or acute attacks of asthma: one (Case 52) with persistent low-grade asthma died unexpectedly within a few minutes of setting up an intravenous infusion of corticotrophin, one (Case 22) died from pneumonia after an operation to remove an emphysematous cyst from the right lung, and one (Case 47) died immediately after an operation for resection of the posterior pulmonary plexus for chronic asthma. The exact cause of death was obscure in a man of 49 with severe terminal attacks of bronchitis associated with emphysema. Relief was obtained on a number of occasions only after intravenous administration of corticotrophin. In his final illness, though bronchial obstruction was relieved, the patient remained anoxic with a low blood pressure and died in coma. He had undoubted emphysema of considerable severity. Permission for postmortem examination was not obtained.

INDETERMINATE GROUP. - This group includes 10 patients in whom no clear indication was found as to the predominating factor: two were male and eight female. Nasal polyps were present in two, emotional factors of a minor nature in three, and a history of occasional bronchitis in four. The sputum contained pus cells in three cases and Str. pneumoniae were cultured from one: in two others the sputum contained only eosinophils at the time of investigation. A family history was obtained in one case only. All died in status asthmaticus or acute attacks of asthma. In one a spontaneous pneumothorax was alsi present and two deaths followed operations for 
oesophagoscopy (Case 21) and gastrectomy (Case 19). Two patients, both women, died within a year of onset of asthma ; one in her second attack of status asthmaticus and one in an acute attack, lasting less than half an hour, after an afternoon walk while on holiday at the seaside.

Bronchitic Group.-In 16 patients, 13 male and three female, asthma apparently developed secondary to respiratory tract infections. In 14 of these there was a clear history of preceding attacks of bronchitis associated with the production of yellow phlegm and mostly confined to the winter months for some time, often many years, before attacks of acute dyspnoea at rest developed. In two, asthma began in the course of the initial attacks of bronchitis or bronchopneumonia and subsequently recurred with bronchitic episodes. Increasing dyspnoea on effort with persistent wheezing was a feature of many of these cases in the terminal stages and the majority coughed up frothy mucus between attacks. Ten were thought to have emphysema on clinical grounds. Eight had associated hypertension with a diastolic blood pressure of over $100 \mathrm{~mm}$. Hg. Pus was repeatedly found in the sputum in all cases ang. pathogenic organisms in many: Str. pneumoniag in five, $H$. influenzae in three, Staph. aureus in three, and Proteus vulgaris in one. Allergf factors were not encountered. Three patients hat an emotional factor and one had had an antrostomy for infection of the maxillary antra All except two had their first attack of asthme after the age of 40 years.

Death was attributed to status asthmaticus it 11 cases, cor pulmonale in two, and in one instance each to pneumonia, emphysema, and hypertensive heart disease. This group therefore differs from the others in the preponderance of males, the lat age of onset, and the frequent presence of emphysema.

\section{Pathology}

A summary of the main findings in 31 cases in which a detailed post-mortem examination was performed is set out in Table III. The cases fath into two main groups, depending on the presence

TABLE III

SUMMARY OF PATHOLOGICAL FINDINGS IN 31 CASES

\begin{tabular}{|c|c|c|c|c|c|c|c|c|c|c|c|c|}
\hline \multicolumn{2}{|c|}{$\begin{array}{l}\text { Case } \\
\text { No. }\end{array}$} & $\underset{\substack{\text { Mucous } \\
\text { Plugs }}}{ }$ & $\begin{array}{l}\text { Thick- } \\
\text { ened } \\
\text { Base- } \\
\text { ment } \\
\text { Mem- } \\
\text { brane }\end{array}$ & $\begin{array}{l}\text { Eosino- } \\
\text { phil } \\
\text { Infil- } \\
\text { tration }\end{array}$ & $\begin{array}{l}\text { Pleural } \\
\text { Ad- } \\
\text { hesions }\end{array}$ & $\begin{array}{l}\text { Chronic } \\
\text { Bron- } \\
\text { chitis }\end{array}$ & $\begin{array}{c}\text { Emphy- } \\
\text { sema }\end{array}$ & $\begin{array}{l}\text { Bronchi- } \\
\text { ectasis }\end{array}$ & $\begin{array}{l}\text { Pneu- } \\
\text { monia }\end{array}$ & Other Pathological Findings & $\begin{array}{l}\text { Clinical } \\
\text { Group }\end{array}$ & 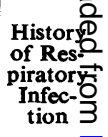 \\
\hline 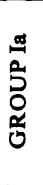 & $\begin{array}{r}1 \\
6 \\
15 \\
24 \\
26 \\
36 \\
56 \\
57\end{array}$ & $\begin{array}{l}++ \\
++ \\
++ \\
++ \\
++ \\
++ \\
++ \\
++\end{array}$ & $\begin{array}{l}0 \\
++ \\
++ \\
++ \\
++ \\
++ \\
++ \\
++\end{array}$ & $\begin{array}{l}++ \\
++ \\
++ \\
++ \\
++ \\
++ \\
++ \\
++\end{array}$ & $\begin{array}{l}0 \\
0 \\
0 \\
0 \\
0 \\
+ \\
0 \\
0\end{array}$ & $\begin{array}{l}\mathbf{0} \\
\mathbf{0} \\
\mathbf{0} \\
\mathbf{0} \\
\mathbf{0} \\
\mathbf{0} \\
\mathbf{0} \\
\mathbf{0}\end{array}$ & $\begin{array}{l}\mathbf{0} \\
\mathbf{0} \\
\mathbf{0} \\
\mathbf{0} \\
\mathbf{0} \\
\mathbf{0} \\
\mathbf{0} \\
\mathbf{0}\end{array}$ & $\begin{array}{l}\mathbf{0} \\
0 \\
0 \\
0 \\
0 \\
0 \\
0 \\
0\end{array}$ & $\begin{array}{l}\mathbf{0} \\
\mathbf{0} \\
\mathbf{0} \\
\mathbf{0} \\
\mathbf{0} \\
\mathbf{0} \\
\mathbf{0} \\
\mathbf{0}\end{array}$ & $\begin{array}{l}\text { Gastroenteritis } \\
\text { Brain-anoxic changes } \\
\text { Chronic duodenal ulcer }\end{array}$ & $\begin{array}{l}\mathbf{F E} \\
\mathbf{I N} \\
\mathbf{I} \\
\mathbf{P} \\
\mathbf{P A} \\
\mathbf{I} \\
\mathbf{P} \\
\mathbf{1}\end{array}$ & 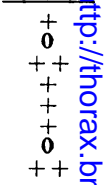 \\
\hline $\begin{array}{l}0 \\
0 \\
0 \\
0 \\
0 \\
0 \\
0\end{array}$ & $\begin{array}{r}5 \\
10 \\
20 \\
28 \\
30 \\
32 \\
41 \\
51 \\
52 \\
53 \\
55 \\
65\end{array}$ & $\begin{array}{l}++ \\
++ \\
++ \\
++ \\
++ \\
++ \\
++ \\
+ \\
++ \\
++ \\
++ \\
++\end{array}$ & $\begin{array}{c}++ \\
++ \\
+ \\
++ \\
++ \\
++ \\
++ \\
++ \\
++ \\
++ \\
++ \\
++\end{array}$ & $\begin{array}{c}++ \\
++ \\
+ \\
++ \\
++ \\
++ \\
++ \\
+ \\
+ \\
++ \\
++ \\
++\end{array}$ & $\begin{array}{c}\mathbf{0} \\
\mathbf{0} \\
++ \\
++ \\
0 \\
+ \\
++ \\
++ \\
0^{+} \\
0_{+}^{+} \\
0^{+}\end{array}$ & $\begin{array}{c}++ \\
+ \\
++ \\
+ \\
+ \\
+ \\
++ \\
++ \\
+ \\
+ \\
+ \\
++\end{array}$ & $\begin{array}{c}+ \\
+ \\
++ \\
++ \\
0 \\
+ \\
+ \\
++ \\
0 \\
++ \\
++ \\
0\end{array}$ & $\begin{array}{l}\mathbf{0} \\
0 \\
0 \\
\\
0 \\
0 \\
0 \\
0 \\
0 \\
0 \\
0 \\
+ \\
0\end{array}$ & $\begin{array}{l}0 \\
0 \\
0 \\
0 \\
0 \\
0 \\
0 \\
0 \\
0 \\
0 \\
0 \\
0 \\
0\end{array}$ & $\begin{array}{l}\text { Cor pulmonale. Healed Ghon } \\
\text { focus }\end{array}$ & $\begin{array}{l}\text { I } \\
\text { FE } \\
\text { FE } \\
\text { IN } \\
\text { PA } \\
\mathbf{I} \\
\mathbf{I} \\
\mathbf{B} \\
\mathbf{I} \\
\mathbf{B} \\
\mathbf{I} \\
\mathbf{B}\end{array}$ & 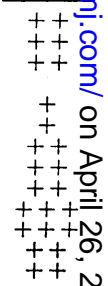 \\
\hline \multirow{4}{*}{$\begin{array}{l}\text { 日 } \\
\stackrel{a}{0} \\
0 \\
0 \\
0\end{array}$} & $\begin{array}{l}12 \\
17\end{array}$ & $\begin{array}{l}0 \\
0\end{array}$ & + & $\begin{array}{l}\mathbf{0} \\
\mathbf{0}\end{array}$ & $\begin{array}{l}+t \\
+t\end{array}$ & $\begin{array}{l}++ \\
++\end{array}$ & $\begin{array}{l}++ \\
++\end{array}$ & $\begin{array}{l}++ \\
++\end{array}$ & $+\underset{0}{+}$ & Cor pulmonale & OA & ++ \\
\hline & $\begin{array}{l}18 \\
19\end{array}$ & $\begin{array}{l}\mathbf{0} \\
\mathbf{0}\end{array}$ & + & + & $\begin{array}{l}++ \\
++\end{array}$ & $\begin{array}{l}++ \\
++\end{array}$ & + & $\begin{array}{l}\mathbf{0} \\
+\end{array}$ & + & Post-operative death. Gastrec- & $\begin{array}{l}\mathbf{F E} \\
\mathbf{I N}\end{array}$ & + \\
\hline & $\begin{array}{l}40 \\
54 \\
58 \\
59\end{array}$ & $\begin{array}{l}\mathbf{0} \\
\mathbf{0} \\
\mathbf{0} \\
\mathbf{0}\end{array}$ & $\begin{array}{l}+ \\
\mathbf{0} \\
+ \\
+\end{array}$ & $\begin{array}{l}\mathbf{0} \\
\mathbf{0} \\
+ \\
\mathbf{0}\end{array}$ & $\begin{array}{l}+ \\
++ \\
+t \\
++\end{array}$ & $\begin{array}{l}++ \\
++ \\
++ \\
++\end{array}$ & $\begin{array}{l}++ \\
++ \\
++ \\
++\end{array}$ & $\begin{array}{l}\mathbf{0} \\
\mathbf{0} \\
+ \\
\mathbf{0}\end{array}$ & $\begin{array}{l}++ \\
0 \\
0 \\
+\end{array}$ & Hypertensive heart disease & $\begin{array}{l}\mathbf{B} \\
\mathbf{B} \\
\mathbf{B} \\
\mathbf{B}\end{array}$ & $\begin{array}{l}+++\frac{c}{\Phi} \\
+++\stackrel{+}{+} \\
++++0\end{array}$ \\
\hline & $\begin{array}{l}63 \\
66 \\
68\end{array}$ & $\begin{array}{l}\mathbf{0} \\
\mathbf{0} \\
\mathbf{0}\end{array}$ & $\begin{array}{l}+ \\
+ \\
0\end{array}$ & $\begin{array}{l}0 \\
+ \\
0\end{array}$ & $\begin{array}{l}++ \\
0 \\
++\end{array}$ & $\begin{array}{l}+ \\
++ \\
+t\end{array}$ & $\begin{array}{l}+ \\
++ \\
++\end{array}$ & $\begin{array}{l}\mathbf{0} \\
\mathbf{0} \\
\mathbf{0}\end{array}$ & $\begin{array}{l}+ \\
+ \\
+\end{array}$ & Hypertensive heart failure & $\begin{array}{l}\mathbf{B} \\
\mathbf{B} \\
\mathbf{B}\end{array}$ & $\begin{array}{l}++\stackrel{\circ}{\overparen{D}} \\
+++\frac{\rho}{0}\end{array}$ \\
\hline
\end{tabular}




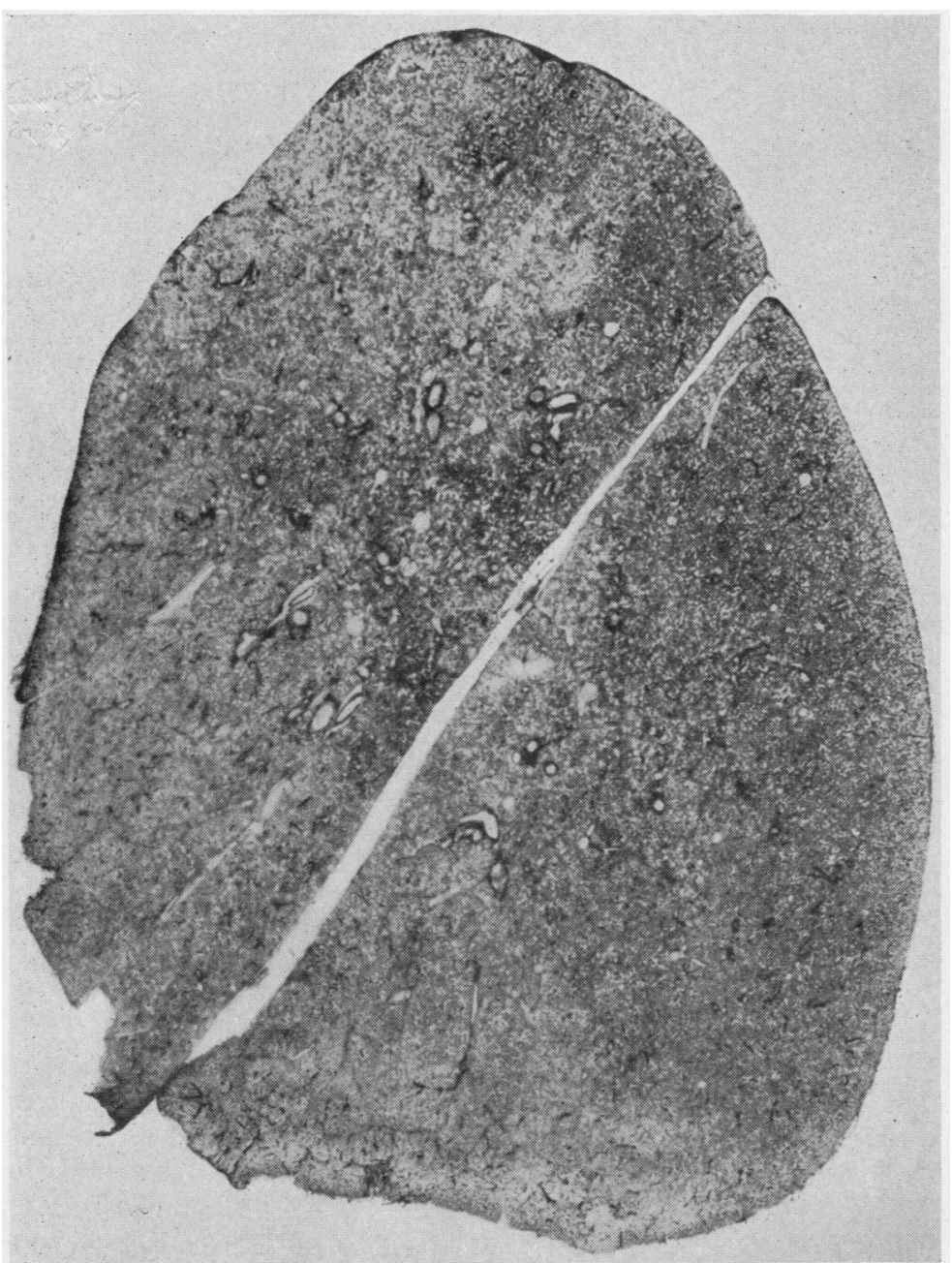

Fig. 1.-Whole lung section.

Distended and congested lung in uncomplicated asthma. No emphysema. $\times \frac{1}{2}$.

cursory inspection of the lung. There is usually some degree of congestion of the lung and often scattered small foci of collapse.

The essential histological lesion in asthma is in the bronchus and is best seen in the medium-sized bronchi 2-5 mm. diameter (Figs. 2 and 3). Mucus fills the lumen of the bronchus. Within the mucus are many eosinophils, a variable number of desquamated bronchial epithelial cells, and, quite often, groups of CharcotLeyden crystals. The bronchial wall is thickened, congested, and oedematous. As a result of muscle contraction the inner border of the bronchial wall is thrown into folds and the muscle appears thickened: there is probably no true hypertrophy of muscle. The lining epithelium is of variable appearance and often stretches of it are shed: foci of squamous metaplasia sometimes occur and mucus-laden goblet cells are common. The glands of the bronchial wall are often prominent and distended with mucus. The basement membrane is thickened and hyaline; appropriate stains show it to consist largely of collagen. There is a cellular infiltration of the whole thickness of the bronchial wall by

or absence of lesions, sufficient to be regarded as the immediate cause of death and due to an attack of asthma.

Group I: Death in an Attack of Asthma.In patients dying from asthma there are certain characteristic pulmonary lesions. The lungs are distended (Fig. 1) and do not collapse when the thorax is opened : they overlap the heart anteriorly and may bear rib markings where they are in contact with the thoracic wall. Many bronchi are plugged by extremely tenacious and viscid mucus, which is usually abundant and is found in bronchi of all sizes. Sometimes the mucus is confined to the smaller bronchi, where it is less obvious and may even escape notice on eosinophil leucocytes and sometimes quite numerous plasma cells.

The bronchioles show somewhat similar lesions (Fig. 4). However, sometimes they are not contracted like the bronchi and their inner wall is not crenated; instead, they are distended by mucus. Mucus may also extend into alveoli and is occasionally seen within macrophages in the alveoli.

In Group I there are 20 cases. All of them showed bronchi plugged with mucus and a moderate or heavy infiltration of the plugs and the bronchial walls by eosinophils. The basement membrane was thickened in all except one case. The exception (Case 1) was an infant with 
FIG. 2.-Medium-sized bronchus with mucus in lumen, thickened wall, and prominent basement membrane. Haematoxylin and eosin.

asthma of only two days' duration. Probably time and repeated attacks of asthma are required to produce a thickened collagenous basement membrane. The other pulmonary changes mentioned above occurred, to a varying degree, in all patients in this group. In eight, apart from a few fine pleural adhesions in one, the only pulmonary lesions were those already described: these form Group Ia, uncomplicated asthma. One case showed mild chronic anoxic changes in the cerebrum with sclerosis of Ammon's horn: this case has already been reported by Leigh (1955). The remaining 12 cases form Group $\mathrm{Ib}$, and all showed additional pulmonary lesions. All had chronic bronchitis with some degree of peribronchial or pulmonary fibrosis. True emphysema with breakdown of alveolar walls was present in nine cases, pleural adhesions in six, and bronchiectasis in one. One had cor pulmonale with a grossly enlarged heart (weight $625 \mathrm{~g}$.): the increased weight was almost entirely due to right ventricular hypertrophy. This case had a healed primary tuberculous complex. Two showed a medullary pressure cone: both brains were congested and oedematous, and they were the only으 ones in - the whole series to exceed the range of $\underset{x}{0}$ normal weights (Roessle and Roulet, 1932).

Group II : OTHER CASES.-Eleven cases remain and none showed bronchi plugged with mucus. Most showed some degree of thickening of the

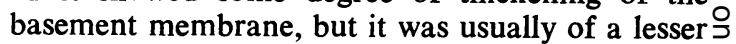
degree than was found in the previous group $\frac{D}{2}$ Infiltration of bronchial walls by eosinophils was uncommon and of moderate degree except in one $\mathcal{N}_{\mathcal{O}}$ instance. All cases in this group had pulmonary lesions not directly attributable to asthma. All had chronic bronchitis, all but one had pleural ${ }^{\circ}$ adhesions, and all but one had emphysema. Four had bronchiectasis.

Varying combinations of pneumonia, hyperten- $-\frac{\overparen{D}}{\Phi}$ sive heart disease, and cor pulmonale accounted $\stackrel{\oplus}{+}$ for death in seven cases, and bronchitis and $\square$ emphysema for a further one. The remaining $\frac{\overrightarrow{+}}{\mathbb{P}}$ three cases need individual comment. Case $19 \stackrel{\odot}{\odot}$ had gross thickening of the bronchial basement $\stackrel{\mathbb{Q}}{\circ}$ membrane and a heavy infiltration of the bronchial 


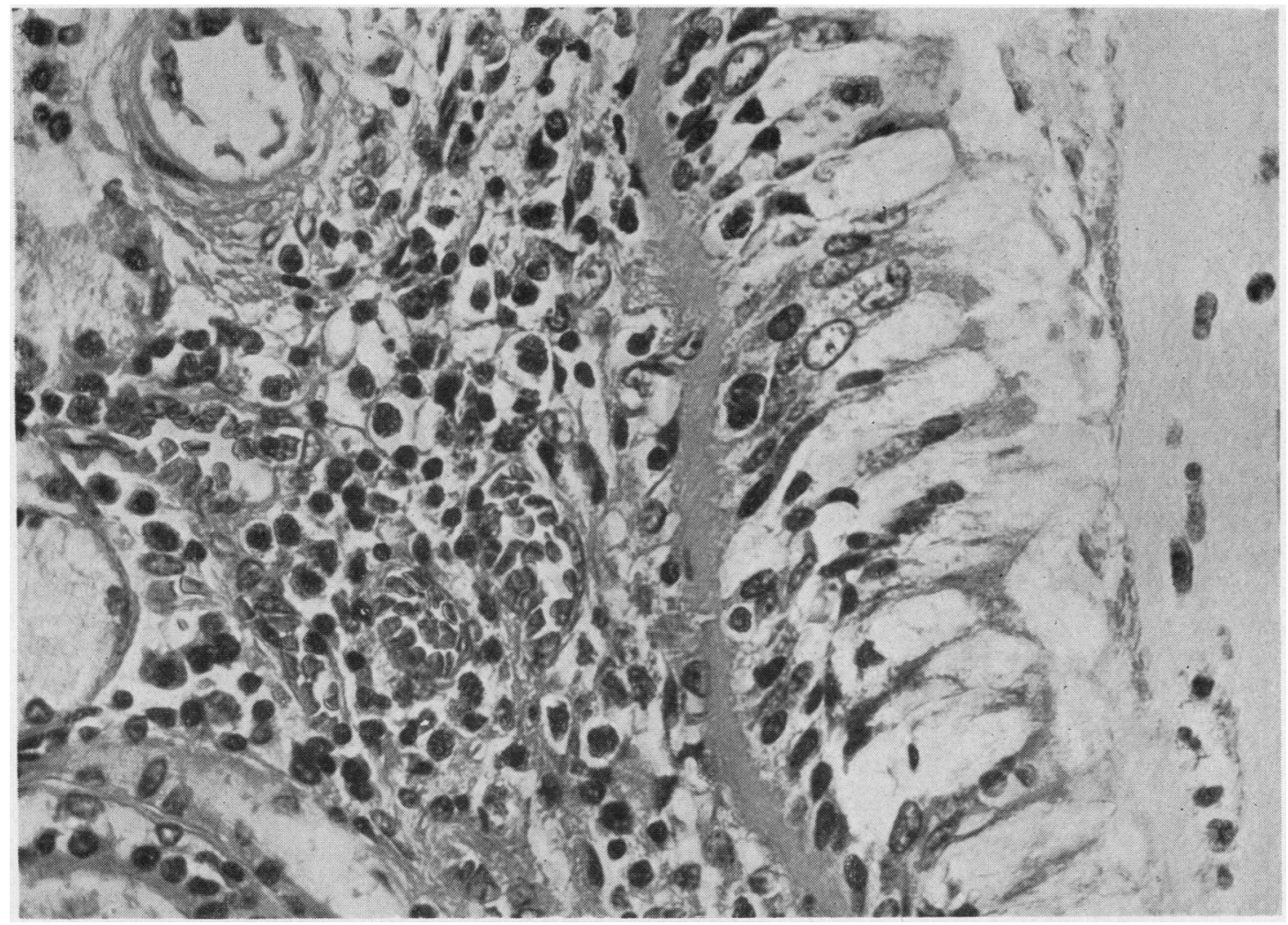

FIG. 3.-Higher power of area from Fig. 1. Eosinophils in bronchial wall and thickened basement membrane. Haematoxylin and eosin. $\times 500$.

walls by eosinophils; although the bronchi were not plugged with mucus these features indicate active asthma. This patient died at the end of a gastrectomy, and the anaesthetist's comment was that throughout the operation bronchospasm was noticed but was controlled by the ether. In this case the asthma may have contributed to the fatal outcome but was certainly not the sole cause of death.

Case 58 showed considerable basement membrane thickening and a rather scanty eosinophil infiltration of the bronchial wall. There was an early widespread acute bronchitis and a fibrinous pericarditis. Here, death was probably due to bronchial infection superimposed on a fading attack of asthma in a patient with a lung much damaged by previous bouts of infection. A similar sequence may have occurred in Cases 12 and 18, though in them there was a well-developed bronchopneumonia.

Finally, in Case 66, there was some basement membrane thickening and a scanty eosinophil infiltrate of the bronchial wall, not really indicative of active asthma, but the lungs were considerably damaged by past infection. The patient was admitted in status asthmaticus, and although bronchospasm was controlled after four days of therapy the patient died, apparently of exhaustion.

NeCropsy Findings in 12 Cases without Histology.-In the remaining 12 cases only the macroscopic findings at necropsy were available. Of these, two died from anaphylactic shock. Six died in an attack of asthma and three of these were complicated by bronchitis and emphysema: one of these three also had a spontaneous pneumothorax. Of the remaining patients two died from bronchitis and emphysema and two post-operatively.

\section{Discussion}

This series of cases is comparable as regards age at onset and death with other published series except that a rather high proportion had symptoms of asthma in the first 10 years of life. In Table IV the age at death in cases in this series 


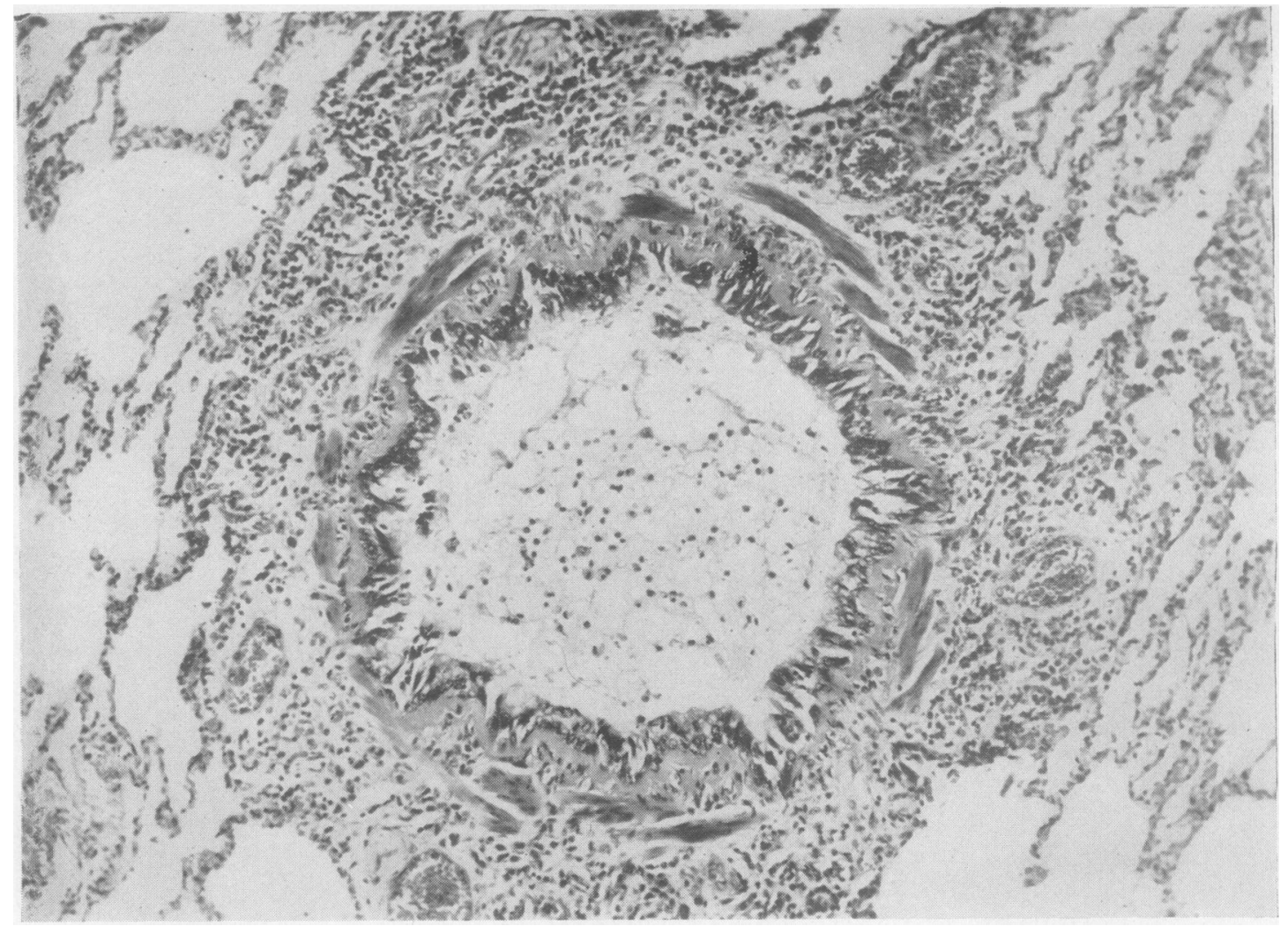

FIG. 4.-Bronchiole showing mucus in lumen, thickened basement membrane, and eosinophil infiltration of wall. Haematoxylin and eosin. $\times 140$.

is compared with the combined figures of cases published by Rackemann (1944), 50 cases ; Earle (1953), 15 cases plus 90 extracted from the literature ; Alexander (1958), 174 cases; and Williams and Leopold (1958), 101 cases. It can be seen that the greatest proportion of deaths occurred in the sixth decade. If, however, only cases of primary asthma are considered, and the cases of asthma secondary to bronchitis are excluded, the greatest number of deaths in our

TABLE IV

AGE AT DEATH IN ASTHMA IN 430 CASES RECORDED IN THE LITERATURE AND IN PRESENT SERIES

\begin{tabular}{c|c|c}
\hline & \multicolumn{2}{|c}{ Percentage of Cases } \\
\cline { 2 - 3 } (Yges & $\begin{array}{c}\text { Literature Series } \\
\text { (430 Cases) }\end{array}$ & $\begin{array}{c}\text { Present Series } \\
\text { (68 Cases) }\end{array}$ \\
\hline $0-9$ & 8 & 4 \\
$10-19$ & 2 & 4 \\
$20-29$ & 6 & 13 \\
$30-39$ & 14 & 21 \\
$40-49$ & 24 & 23 \\
$50-59$ & 27 & 22 \\
$60+$ & 20 & 12 \\
\hline
\end{tabular}

series occurred in the fifth decade. One further important feature emerges on analysis of ages at onset of asthma and age at death. Reference to Tables I and II and to other published cases shows that many patients dying in the fifth to seventh decades have a short history. The mean period between onset of primary asthma and death in our 28 cases with onset before 20 years of age was 27.2 years, compared with 6.4 years in our $\rightarrow$ 24 cases with onset after the age of 40 . This point, that cases with onset of asthma after 40 N years of age run a short course, was first made by Rackemann (1944), who referred to them as suffering from "asthma gravis."

A point of considerable importance is that previous attacks of status asthmaticus had been recorded in 42 of the 54 patients dying directly from asthma and in six of the remaining 12 cases. The frequency of previous attacks of status asthmaticus in fatal cases has also been noted by Pearson (1958) and Williams and Leopold (1958). In contrast to those whose illness was brief and 
stormy throughout, there were others in whom attacks of status asthmaticus developed suddenly after years of mild, easily controlled asthma, in one case after an interval of 50 years of complete freedom from attacks. In five patients (Cases 19, $21,32,39$, and 43) a single sudden acute attack in the course of otherwise mild disease led to a fatal termination; two of these were after operation. Patients with status asthmaticus sometimes died suddenly and unexpectedly in the recovery phase after partial control had been achieved. Attention is drawn to the fact that death in status asthmaticus is not uncommonly associated with pathological changes, such as pulmonary infection or bronchiectasis or cor pulmonale, which are only indirectly related to asthma.

Three of our patients (Cases 7, 25, and 52) died from constitutional reactions to pollen, "pyelectan," and corticotrophin respectively, administered therapeutically or for diagnostic purposes. This hazard in asthmatics is an important one to recognize, as pointed out by Midttun (1954) and Bruun (1955). Four patients died post-operatively, two (Cases 22 and 47) after surgery carried out for asthma, and two (Cases 19 and 21) of asthma after surgery for unrelated conditions.

On clinical grounds patients could be placed in three main groups: (1) Cases with evidence of allergic sensitivity of extrinsic origin and includes the patients with flexural eczema and pollen or other allergic sensitivities ; (2) cases with no clear evidence of extrinsic precipitating factors who correspond to Rackemann's " intrinsic cases" and includes our groups labelled psychological, infective, and indeterminate ; (3) cases in which asthma developed secondary to bronchitis (secondary asthma).

Table $\mathrm{V}$ shows some of the similarities and differences between these groups. The main differences appear to be the higher incidence of family history of asthma among the extrinsic group and the earlier age of onset and death in this

TABLE V

MAJOR FEATURES OF THREE CLINICAL GROUPS AMONG 68 FATAL CASES OF ASTHMA

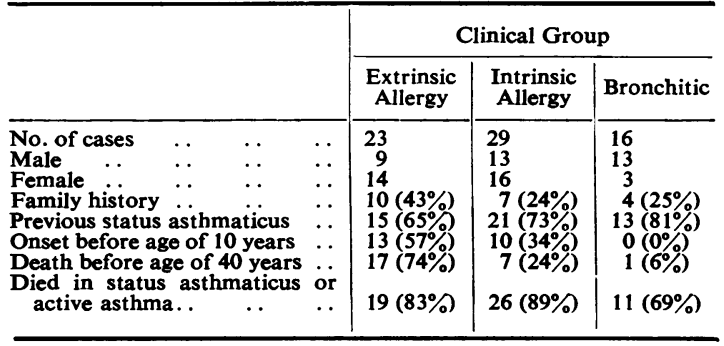

group. The bronchitic group contains a higher proportion of males. The post-mortem findings in some of the cases in the various groups can be seen in Table III. Patients with primary asthma whether from the extrinsic allergic or intrinsic groups account for all the cases classified on histological grounds as dying from "uncomplicated asthma" (Group Ia). Others from the same clinical groups show evidence of lung damage as a result of respiratory infection in addition to the characteristic changes of asthma to be described (Group Ib). Still others die from pneumonia or cor pulmonale and show no evidence of active asthma at the time of death (Group II). It is of interest that on clinical grounds, including sputum examination, infection was considered to play a part in 17 of the 23 extrinsic cases and 22 of 29 intrinsic cases.

Patients with asthma secondary to bronchitis in most cases show the appearances of advanced bronchitis with emphysema, but some (Cases 51, 53, and 65) have in addition the eosinophil infiltration and mucus plugs, usually scanty, seen in primary asthma. It therefore appears that primary asthma may be complicated by bronchial infection and its sequelae, whereas bronchitis may be associated with histological as well as clinical evidence of asthma.

Of the pathological findings in the lungs in deaths due to asthma, three are especially important: mucous plugging of bronchi and, in the bronchial wall, infiltration by eosinophil leucocytes and a thickened basement membrane. Together, these features are diagnostic of severe active asthma. Obstruction of the bronchial lumen by mucous plugs is now generally regarded as the main factor impairing pulmonary ventilation in these cases, though spasm of the bronchial muscle and congestion of the bronchial wall may help to reduce the airway. The degree to which bronchi are plugged with mucus varies from case to case. In general, the more damaged the lungs were as a result of past infection, the less the degree of mucous plugging required to cause death. This was especially noticeable in Case 51 where there was considerable pulmonary fibrosis and emphysema (Fig. 5) with but little plugging. In Case 20 also there was relatively little plugging but considerable structural lung damage and severe cor pulmonale. That other coexistent disease enhances the effect of bronchial plugging is shown by Case 1 , a child with gastro-enteritis dying in its first attack of asthma.

Thickening of the bronchial basement membrane is not found only in asthma, but occurs 
also in chronic bronchitis and in many chronic lung conditions. It does appear to be more frequent, and of a greater degree, in cases of asthma. In the present series it was of greater degree in patients dying in an attack of asthma than in those not dying in an attack, or in cases, not in this series, of chronic bronchitis uncomplicated by asthma that we have examined. Furthermore, repeated bronchial biopsies on patients with asthma have shown the basement membrane to be more thickened during attacks than between attacks. Somewhat similar changes also occur in the degree of eosinophil infiltration of the bronchial wall: we have studied these changes not only in necropsy material but also in repeated biopsies during life. During an attack of asthma there is a considerable cellular infiltration of the bronchial wall and eosinophils are the predominant cell in this infiltrate. After an attack the number of eosinophils rapidly decreases and between attacks few such cells are present. In bronchitics few eosinophils are present even when there is a heavy infiltration of the bronchial wall by other types of inflammatory cells. Hence, the degree of eosinophil infiltration of the wall and the thickness of the basement membrane may serve to assess the degree of activity of asthma. Williams and Leopold (1958) considered eosinophil infiltration of the bronchial wall to be the hallmark of active asthma. If it is some days or weeks after an attack of asthma there may be no histological changes by which asthma can be diagnosed.

This view is contrary to that of Unger (1952), who does not regard any of the lesions found to be pathognomonic. Gloor (1954), however, considers that the findings of excessive production of mucus, eosinophil infiltration of the bronchial walls, and thickened basement membrane indicate a diagnosis of bronchial asthma even though the patient did not die in an asthmatic attack.

Shedding of ciliated epithelium into the bronchial lumen was frequent. Houston, De Navasquez, and Trounce (1953) noted this and considered it an important mechanism in the production of plugging as it led to mucus being lodged in the bronchial tree. This loss of epithelium may also predispose the bronchi to infection and account for the superimposition of bronchitis and pulmonary infection on asthmatic attacks, as in our Cases 12, 18, and 58. This last group of cases is clinically important. We agree with Williams and Leopold (1958) that it may be difficult sometimes, on purely clinical grounds, to differentiate status asthmaticus from acute bronchitis. In any patient with status 
asthmaticus who fails to respond to routine asthma therapy it is important to consider whether the allergic component may have been controlled and that the patient has insidiously developed an acute bronchitis and needs intensive antibiotic therapy.

Although distension of the lungs was noted in all patients dying from asthma, not all showed emphysema. In our cases of uncomplicated asthma the lungs showed only distension: this had been noted by Gough (1951), who described the lungs of these cases as simply overdistended and likened them to those of a drowned person. True emphysema with destruction of alveolar walls was found only in cases with evidence of fibrosis following bronchitis or pneumonia. From Table III it can be seen that a history of repeated respiratory infection is more common in Groups Ib and II than Group Ia. This finding is in accord with the observation of Leopold and Gough (1957) that the centrilobular form of emphysema is related to chronic bronchitis.

The importance of respiratory infections in asthmatics is also shown in other ways. Death from uncomplicated asthma was relatively uncommon in our series: well over half the patients dying in an attack of asthma had evidence of lung damage due to infection, and among asthmatics not dying in an attack of asthma the majority died as a direct result of pulmonary infection or its sequelae. Of the 160 cases from the literature reviewed by Earle (1953), 35\% were said to be examples of uncomplicated asthma. This figure is certainly too high, for in some of the cases right ventricular hypertrophy was noted and some of the series reviewed were concerned only with cases dying in an attack of asthma. More accurate figures can be obtained by combining the series of Thieme and Sheldon (1938), Rackemann (1944), Gay (1946), and Winer, Beakey, and Segal (1950) where individual causes of death are given for a total of 137 patients. These four papers considered all modes of death in large series of patients with asthma and were not confined to those dying in an attack of asthma. Forty per cent. died in an attack of asthma but $13 \%$ also had some pulmonary infection or other complications, $37 \%$ died as a result of pulmonary infection or its sequelae, and, of the remainder dying from intercurrent disease, $16 \%$ had some pulmonary lesions due to infection. The figures cited relate to "major causes of death" and no doubt the pure asthma group included some cases with lung lesions not advanced enough to be labelled as major. Deaths from genuinely uncomplicated asthma would thus be less than
$26 \%$ of the total, whilst major lung lesions due to infection were present in $66 \%$.

Bronchial and pulmonary infections are thus a bad omen in a patient with asthma. They are responsible for many deaths either directly or by reducing the reserve capacity of the lung so that attacks of asthma become more lethal. Furthermore, not only may respiratory infections affect a patient with asthma of purely allergic origin but some patients with chronic bronchitis develop asthma, die from it, and at necropsy show the characteristic lesions of active asthma.

\section{SUMMARY}

The clinical features of 68 fatal cases of asthma are discussed together with detailed post-mortem findings in 31 . The cases are divided into those with primary asthma and those in whom asthmatic attacks developed in the course of chronic or recurrent bronchitis (secondary asthma).

In cases of primary asthma, whether due mainly to extrinsic allergy or intrinsic factors, death may be due solely to asthma with a characteristic pathology. Many of these cases are, however, complicated by respiratory infections which may cause death directly, or cause lung damage which makes subsequent asthmatic attacks more readily lethal.

Some patients with chronic or recurrent bronchitis develop symptoms of asthma in the course of the disease. This group is, generally speaking, easily distinguished from the cases of primary asthma both on clinical and pathological grounds, but in some cases the characteristic pathological changes seen in primary asthma can be demonstrated in addition to those typical of bronchitis.

We should like to express our thanks to colleagues on the staff of King's College Hospital who have allowed us to include in this series five cases admitted under their care, to Drs. Denis Leigh, M. O. Skelton, and I. G. Williams for information and specimens relating to individual patients, and to Mr. G. Harwood for technical help. Part of the histological work was carried out with the help of a grant to one of us (B. S. C.) from the King's College Hospital and Medical School Research Committee.

\section{REFERENCES}

Alexander, H. L. (1958). Proceedings of the Third International Congress of Allergology, p. 109. Flammarion, Paris.

Bruun, E. (1955). Acta allerg. (Kbh.), 8, 134.

Cardell, B. S. (1956). Int. Arch. Allergy, 9, 189.

Earle, B. V. (1953). Thorax, 8, 195. 
Gay, L. N. (1946). The Diagnosis and Treatment of Bronchial Asthma. Baillière, Tindall and Cox, London.

Gloor, F. (1954). Virchows Arch. path. Anat., 325, 189.

Gough, J. (1951). Lancet, 1, 161.

- (1957-58). Harvey Lect., 53, 171.

- and Wentworth, J. E. (1949). J. roy. micr. Soc., 69, 231.

Houston, J. C., De Navasquez, S., and Trounce, J. R. (1953). Thorax, 8, 207.

Huber, H. L., and Koessler, K. K. (1922). Arch. intern. Med., 30, 689.

Leigh, D. (1955). Psychosom. Med., 17, 232.

Leopold, J. G., and Gough, J. (1957). Thorax, 12, 219.

Midttun, O.(1954). Acta allerg. (Kbh.), 7, 186
Pearson, R. S. B. (1958). Ibid., 12, 277.

Rackemann, F. M. (1944). J. Allergy, 15, 249.

Robertson, C. K., and Sinclair, K. (1954). Brit. med. J., 1, 187.

Roessle, R., and Roulet, F. (1932). Mass und Zahl in der Patholog Springer, Berlin.

Thieme, E. T., and Sheldon, J. M. (1938). J. Allergy, 9, 246.

Unger, L. (1952). Prog. Allergy, 3, 142.

Williams, D. A., and Leopold, J. G. (1958). Proceedings of the Thir\& International Congress of Allergology, p. 119. Flammarion, Paris.

Winer, B. M., Beakey, J. F., and Segal, M. S. (1950). Ann. internMed., 33, 134 